\title{
Influence of angiotensin converting enzyme inhibition on relation of atrial natriuretic peptide concentration to atrial pressure in heart failure
}

\author{
H Berglund, O Nyquist, B Beermann, M Jensen-Urstad, E Theodorsson
}

\begin{abstract}
Objective-To examine the relation between haemodynamics and atrial natriuretic peptide concentration during short term angiotensin converting enzyme inhibition.

Design-Patients were randomly allocated to receive placebo or one of three doses of the angiotensin converting enzyme inhibitor ramipril.
\end{abstract}

Setting-Cardiac units of two tertiary referral hospitals.

Subjects-38 Patients with stable congestive heart failure caused by ischaemic heart disease.

Methods-Data were collected over a 24 hour period and assessed with the aim of distinguishing between the haemodynamic effects on plasma concentrations of atrial natriuretic peptide and the direct effects of the study drug, vasopressin concentrations, and angiotensin converting enzyme activity.

Results-Pulmonary capillary wedge pressure was the main predictor of the plasma concentration of atrial natriuretic peptide. A higher plasma concentration of this peptide with a given pulmonary capillary wedge pressure was found after 24 hours of treatment with $2.5 \mathrm{mg}$ and 5 mg of ramipril. Plasma concentration of the active metabolite, change in arginine vasopressin concentration or degree of angiotensin converting enzyme inhibition did not significantly predict change in plasma concentration of atrial natriuretic peptide or in the ratio of atrial natriuretic peptide concentration to pulmonary capillary wedge pressure.

Conclusions-A gradual increase in plasma concentration of atrial natriuretic peptide with a given pulmonary capillary wedge pressure, occurs during short term high degree inhibition of angiotensin converting enzyme. The causative mechanisms are yet to be identified. Such a change in the relation between central haemodynamics and atrial natriuretic peptide concentration may contribute to the beneficial effects of angiotensin converting enzyme inhibition in patients with congestive heart failure due to ischaemic heart disease.

(Br Heart f 1994;72:521-527)
Several neuroendocrine responses occur in heart failure. The vasoconstrictor and sodium retentive forces seem to overrule the counterbalancing vasodilative systems. ${ }^{12}$ The use of angiotensin converting enzyme inhibitors in treating congestive heart failure is one neuroendocrinological approach to correct this imbalance. ${ }^{3}$ Atrial natriuretic peptide is a hormone with vasodilating and natriuretic properties. ${ }^{45}$ Its secretion from the myocytes is probably modulated by stretch receptors. ${ }^{6-8}$ In most circumstances this peptide seems to suppress the renin-angiotensin-aldosterone system. ${ }^{9-11}$ Thus, it may be regarded as a hormone counteracting excessive vasoconstrictive and sodium retentive forces, including activation of the renin-angiotensin-aldosterone system, as are found in patients with congestive heart failure.

In vivo intravenous administration of vasopressin, angiotensin II, noradrenaline, and endothelin increases the plasma concentration of atrial natriuretic peptide. ${ }^{12-14}$ All these substances are potent vasoconstrictors with systemic and central pressure effects, which could explain the increase in the plasma concentration of this peptide. Whether this is the sole cause of the atrial natriuretic peptide release produced by these substances in vivo remains to be determined. In a rat heart-lung preparation, the addition of angiotensin II or vasopressin to the perfusate did not significantly affect the basal secretion of atrial natriuretic peptide, or response of this secretion to increasing venous return, indicating that the ability of these hormones to facilitate atrial natriuretic peptide secretion in vivo may be secondary to their effects on atrial pressures. ${ }^{15}$ In a study in which atrial pressures were kept constant by simultaneous nitroprusside infusion, the effect of phenylephrine on the plasma concentration of atrial natriuretic peptide was abolished, while the effect of angiotensin II was maintained. ${ }^{16}$

Atrial pressures are strong predictors of plasma concentrations of atrial natriuretic peptide. ${ }^{7}$ Angiotensin converting enzyme inhibition is expected to reduce atrial pressures in patients with heart failure. ${ }^{3}$ Even so, studies in humans have yielded conflicting results concerning the effect of treatment with an angiotensin converting enzyme inhibitor on the endogenous plasma concentration of atrial natriuretic peptide, and an increase, a reduction, and little effect have been reported in 
different studies. ${ }^{17-19}$ In addition, short term angiotensin converting enzyme inhibition does not seem to influence the clearance of atrial natriuretic peptide. ${ }^{19}$ Resetting of the atrial natriuretic peptide response to haemodynamic alteration during angiotensin converting enzyme inhibition has also been suggested. ${ }^{20}$ Furthermore, early studies in vitro suggested that angiotensin converting enzyme inhibitors slowed the metabolism of atrial natriuretic peptide. ${ }^{21}$

From the studies cited it is clear that the interactions between the renin-angiotensinaldosterone system and atrial natriuretic peptide are complex and that the net effect of angiotensin converting enzyme inhibition on the plasma concentration of atrial natriuretic peptide in patients with heart failure is not evident. We therefore addressed three questions: Are atrial pressures and plasma concentrations of atrial natriuretic peptide altered during short term inhibition of angiotensin converting enzyme? Is the postulated relation between atrial natriuretic peptide and atrial pressures solely dependent on the atrial pressure, or is it also determined by the degree of angiotensin converting enzyme inhibition? Are early and late responses consistent?

\section{Patients and methods}

The study comprised 38 patients with heart failure (functional class III of the New York Heart Association classification) due to ischaemic heart disease. There were nine women and 29 men, with a mean age of 67 (SD 7) years (range 51-77).

The patients were randomly allocated to one of four treatment groups and received either placebo or one of three doses of oral ramipril. All patients had been clinically stable for a minimum of four weeks before entering the study, and treatment was restricted to diuretics, digoxin, and $\beta$ blockers which were unchanged in dosage during this stabilisation period. The last dose of concomitant drug treatment was given in the morning of the study day. Informed consent was obtained from all patients, and the study was approved by the local ethics committee.

\section{RAMIPRIL}

Oral ramipril is rapidly absorbed, and the peak plasma concentration is reached within one hour in a dose dependent fashion. Ramipril is rapidly hydrolysed, its plasma half life being about 1-2 hours. The primary site of hydrolysis is in the liver. The active diacid metabolite (ramipril diacid), ramiprilat, reaches its peak plasma concentration at 2-4 hours. The half life in healthy subjects during the major distribution-elimination phase ranges between 1.1 and 4.5 hours. ${ }^{22}$ In addition, the metabolite has a prolonged terminal phase of elimination. The acute haemodynamic response in patients with congestive heart failure starts about 1 to 2 hours after oral administration, and maximal effects are usually observed after 4 to 8 hours. ${ }^{22}$ Ramipril has been coadministered with food and digoxin without any relevant change in absorption. ${ }^{22}$

\section{PROTOCOL}

The patients were examined while supine. Right heart catheterisation was performed with a double lumen, flow directed catheter from an antecubital vein or the femoral vein. Blood pressure was recorded from a catheter in a brachial artery. The heart rate was obtained from a continuously monitored electrocardiogram lead.

After completion of the catheterisation procedures, the patients had 30 minutes of rest while supine before the baseline measurements; immediately after the baseline measurements either oral placebo or $1.25 \mathrm{mg}$, $2.5 \mathrm{mg}$, or $5 \mathrm{mg}$ of ramipril was given. Haemodynamic variables were measured 3, 6, and 24 hours after the drug intake. Blood samples for measurement of atrial natriuretic peptide concentration and angiotensin converting enzyme activity were drawn from the brachial artery simultaneously on all four occasions in all patients. Plasma samples for determination of the plasma renin activity and ramiprilat concentration were obtained in all groups but were subsequently analysed only in the treatment groups. Meals were served roughly $2,7,11$, and 23 hours after treatment.

\section{CHEMICAL ASSAYS}

Blood samples were drawn into chilled heparinised tubes and centrifuged within 10 minutes. Plasma samples were stored at $-20^{\circ} \mathrm{C}$ until processed. Plasma concentrations of atrial natriuretic peptide were measured by radioimmunoassay. ${ }^{23}$ In 23 healthy subjects with a mean age of 63 (4) years the mean plasma concentration of immunoreactive atrial natriuretic peptide in blood samples handled as above was 18 (9) $\mathrm{pmol} / \mathrm{l}$. A radioimmunoassay was used for measurement of ramipril and ramiprilat in serum or plasma. ${ }^{24}$ Angiotensin converting enzyme activity in plasma was assayed by cleavage of tritiated hip-gly-gly to tritiated hippuric acid and glycine dipeptide. Tritiated hippuric acid was separated from the substrate by extraction with ethyl acetate and measured by liquid scintillation counting (radiochemical assay; Ventrex, Portland, Ohio). ${ }^{25}$ Plasma renin activity was determined by angiotensin I radioimmunoassay (Sorin Biomedica, Italy). ${ }^{26}$ Plasma concentrations of arginine vasopressin were measured by a commercially available radioimmunoassay (Bühlman, Basle). ${ }^{27}$

\section{STATISTICS}

The data in the tables and text are presented as means (SD). The Anderson-Darling test was used to test for Gaussian distribution in the data. ${ }^{28}$ Since there was no strong evidence for non-Gaussian distribution of the measured variables parametric statistics were used. Differences between groups at baseline were tested by one way analysis of variance. Differences in responses between the groups 
Table 1 Haemodynamic data

\begin{tabular}{|c|c|c|c|c|c|}
\hline $\begin{array}{l}\text { Ramipril } \\
\text { (mg) }\end{array}$ & $\begin{array}{l}\text { No of } \\
\text { patients }\end{array}$ & Baseline & $3 h$ & $6 h$ & $24 h$ \\
\hline \multicolumn{6}{|c|}{ Right atrial mean pressure $(m m \mathrm{Hg}$ ) } \\
\hline 0 & 10 & $6.0(1.8)$ & $5 \cdot 6(2 \cdot 7)$ & $5 \cdot 0(2 \cdot 2)$ & $4 \cdot 3(2 \cdot 1)^{\star \star}$ \\
\hline $1 \cdot 25$ & 9 & $6.9(2.6)$ & $5.4(3.4)^{\star \star}$ & $5.7(3.7)^{\star}$ & $5.8(2.4)^{\star}$ \\
\hline $2 \cdot 5$ & 10 & $5 \cdot 7(2 \cdot 2)$ & $4 \cdot 4(2 \cdot 1)$ & $4 \cdot 5(2 \cdot 8)$ & $4.9(2.9)$ \\
\hline 5 & 9 & $7 \cdot 2(3 \cdot 9)$ & $5 \cdot 2(2 \cdot 6)^{\star}$ & $5 \cdot 7(3 \cdot 7)$ & $5 \cdot 6(2 \cdot 6)$ \\
\hline \multicolumn{6}{|c|}{ Pulmonary capillary wedge pressure $(m m \mathrm{Hg})$} \\
\hline 0 & 10 & $15 \cdot 7(8 \cdot 1)$ & $13 \cdot 1(8 \cdot 0)^{\star}$ & $16 \cdot 4(9 \cdot 3)$ & $13.6(7 \cdot 1)$ \\
\hline 1.25 & 9 & $17 \cdot 4(9 \cdot 7)$ & $14.7(9.9)$ & $16 \cdot 4(9 \cdot 3)$ & $16.6(8.6)$ \\
\hline $2 \cdot 5$ & 10 & $12.9(3.5)$ & $10.7(3.3)^{\star}$ & $9.6(3.0)^{\star \star}$ & $9 \cdot 3(3 \cdot 3)^{\star \star \star}$ \\
\hline 5 & 9 & $24 \cdot 3(11 \cdot 7)$ & $17 \cdot 6(8 \cdot 7)^{\star \star \star}$ & $18(8 \cdot 8)^{\star \star \star}$ & $19 \cdot 3(9 \cdot 6)^{\star \star}$ \\
\hline \multirow{2}{*}{\multicolumn{6}{|c|}{ Mean arterial pressure $(\mathrm{mm} \mathrm{Hg})$}} \\
\hline 0 & 10 & $90(13)$ & & & $89(13)$ \\
\hline $1 \cdot 25$ & 9 & $91(13)$ & 91 (14) & $86(10)^{\star}$ & $87(11)^{\star}$ \\
\hline 2.5 & 10 & $86(9)$ & $82(10)$ & $83(14)$ & $85(12)$ \\
\hline & & $94(11)$ & $78(16)^{\star \star}$ & $81(17)^{\star \star \star}$ & $86(13)^{\star \star}$ \\
\hline \multicolumn{6}{|c|}{ Heart rate (beats/min) } \\
\hline 0 & 10 & 77 (14) & $75(14)$ & $78(15)$ & $80(15)$ \\
\hline $1 \cdot 25$ & 9 & $72(10)$ & 71 (11) & $71(10)$ & $73(8)$ \\
\hline 2.5 & 10 & 68 (11) & $69(9)$ & $69(9)$ & $76(10)^{\star \star}$ \\
\hline 5 & 9 & $72(9)$ & 70 (5) & $71(7)$ & 77 (13) \\
\hline \multicolumn{6}{|c|}{ Cardiac index $\left(\mathrm{l} / \mathrm{min} / \mathrm{m}^{2}\right)$} \\
\hline 0 & 10 & $2 \cdot 18(0.24)$ & $2.32(0.31)$ & $2.32(0.33)$ & $2.47(0.31)^{\star}$ \\
\hline $1 \cdot 25$ & 9 & $2.24(0.47)$ & $2.30(0.49)$ & $2.36(0.44)$ & $2.51(0.50)^{\star \star \star}$ \\
\hline $2 \cdot 5$ & 10 & $2 \cdot 10(0.55)$ & $2.46(0.54)^{\star \star}$ & $2.40(0.56)^{\star \star}$ & $2.48(0.89)^{\star \star \star}$ \\
\hline & 9 & $2 \cdot 11(0.32)$ & $2.39(0.40)^{\star}$ & $2.28(0.66)$ & $2.51(0.38)^{\star}$ \\
\hline \multicolumn{6}{|c|}{ Systemic vascular resistance $\left(\right.$ dyn $\left.\cdot \mathrm{s} \cdot \mathrm{cm}^{-5}\right)$} \\
\hline 0 & & $1658(242)$ & $1533(291)$ & $560(202)$ & $1493(259)$ \\
\hline $1 \cdot 25$ & 9 & $1622(403)$ & $1610(423)$ & $449(280)^{\star}$ & $1379(318)^{\star \star \star}$ \\
\hline $2 \cdot 5$ & 10 & $1712(498)$ & $1398(333)^{\star \star \star}$ & $442(350)^{\star \star}$ & $1269(193)^{\star \star \star}$ \\
\hline & 9 & $1795(384)$ & $1383(480)^{\star \star \star}$ & $568(632)^{\star}$ & $1451(349)^{\star \star}$ \\
\hline
\end{tabular}

were tested by two way repeated measures analysis of variance factoring for treatment group and time, with multiple comparisons according to Fisher's protected least significant differences. Changes with time, within each group were tested by one way analysis of variance, repeated measurements, and appropriate contrasts. Relations between haemodynamic and hormonal data were analysed by

Table 2 Ramiprilat concentration enzyme activities, and plasma hormone concentrations

\begin{tabular}{|c|c|c|c|c|c|}
\hline $\begin{array}{l}\text { Ramipril } \\
\text { (mg) }\end{array}$ & $\begin{array}{l}\text { No of } \\
\text { patients }\end{array}$ & Baseline & $3 h$ & $6 h$ & $24 h$ \\
\hline \multicolumn{6}{|c|}{ Ramiprilat (ng/ml) } \\
\hline 0 & 10 & $\overline{0}=$ & - & $\overline{0}$ & $\overline{-1}$ \\
\hline $1 \cdot 25$ & 9 & $0.5(0.6)$ & $2 \cdot 6(0 \cdot 7)$ & $2 \cdot 2(0 \cdot 7)$ & $1.5(0.4)$ \\
\hline $\begin{array}{l}2 \cdot 5 \\
5\end{array}$ & 10 & $0.5(0.3)$ & $3.5(1.0)$ & $2.9(1.0)$ & $1.5(0.3)$ \\
\hline & & $0.2(0 \cdot 3)$ & $19 \cdot 1(9 \cdot 7)$ & $12.5(5 \cdot 6)$ & $2.4(1.5)$ \\
\hline \multirow{5}{*}{$\begin{array}{l}0 \\
1 \cdot 25 \\
2 \cdot 5 \\
5\end{array}$} & \multicolumn{4}{|c|}{ Angiotensin converting enzyme ( $\mathrm{nmol} / \mathrm{ml} / \mathrm{min}$ ) } & \multirow{5}{*}{$\begin{array}{c}98(30)^{\star} \\
48(14)^{\star \star \star} \\
22(1)^{\star \star \star} \\
9(8)^{\star \star \star}\end{array}$} \\
\hline & & $105(32)$ & $106(33)$ & $101(36)$ & \\
\hline & 9 & $119(28)$ & 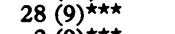 & $32(2)^{\star \star \star \star}$ & \\
\hline & 10 & $91(5)$ & $2(9)^{\star \star \star}$ & $19(9)^{\star \star \star}$ & \\
\hline & 9 & $65(21)$ & $2(3)^{\star \star \star}$ & $2(2)^{\star \star \star}$ & \\
\hline \multirow{5}{*}{$\begin{array}{l}0 \\
1 \cdot 25 \\
2 \cdot 5 \\
5\end{array}$} & \multicolumn{4}{|c|}{ Angiotensin converting enzyme inhibition (\%) } & \multirow{5}{*}{$\begin{array}{c}6(7) \\
59(10) \\
76(11) \\
87(12)\end{array}$} \\
\hline & 10 & 0 & $-1(7)$ & $7(12)$ & \\
\hline & 9 & 0 & $76(7)$ & $74(7)$ & \\
\hline & 10 & 0 & $86(12)$ & $89(11)$ & \\
\hline & & 0 & $97(5)$ & $97(3)$ & \\
\hline \multirow{5}{*}{$\begin{array}{l}0 \\
1 \cdot 25 \\
2 \cdot 5 \\
5\end{array}$} & \multicolumn{4}{|c|}{ Renin (ng angiotensin $I / m l / h$ ) } & \multirow{5}{*}{$\begin{array}{l}\overline{6 \cdot 1}(4 \cdot 2) \\
7 \cdot 2(6 \cdot 0) \\
6 \cdot 2(9 \cdot 2)\end{array}$} \\
\hline & 10 & - & - & - & \\
\hline & 9 & $4.5(3.0)$ & $7 \cdot 4(4 \cdot 5)^{\star}$ & $6 \cdot 2(4 \cdot 9)$ & \\
\hline & 10 & $5 \cdot 0(4 \cdot 6)$ & $9.9(8.4)^{\star}$ & $9 \cdot 7(7 \cdot 2)^{\star}$ & \\
\hline & 9 & $5 \cdot 0(7 \cdot 6)$ & $10 \cdot 0(13 \cdot 2)^{\star}$ & $8 \cdot 7(13 \cdot 5)$ & \\
\hline \multicolumn{6}{|c|}{ Atrial natriuretic peptide (pmol/l) } \\
\hline 0 & 10 & $66(51)$ & $56(47)$ & $78(60)$ & $58(40)$ \\
\hline $1 \cdot 25$ & 9 & $64(52)$ & $51(41)^{\star}$ & $55(47)$ & $57(38)$ \\
\hline $2 \cdot 5$ & 10 & $49(27)$ & $41(19)$ & $43(19)$ & $44(18)$ \\
\hline & 9 & $84(53)$ & $70(49)^{\star}$ & $75(60)$ & $83(55)$ \\
\hline \multicolumn{6}{|c|}{ Arginine vasopressin (pmolll) } \\
\hline & & $4 \cdot 3(2 \cdot 8)$ & $3.0(2 \cdot 3)^{\star}$ & $2.6(1.9)^{\star}$ & $1.9(0.4)^{\star \star}$ \\
\hline $1 \cdot 25$ & 9 & $4.0(1.4)$ & $2 \cdot 7(1 \cdot 1)^{\star}$ & $2.3(0.9)^{\star}$ & $1 \cdot 8(0 \cdot 3)^{\star \star \star}$ \\
\hline $2 \cdot 5$ & 10 & $3.9(1 \cdot 2)$ & $2 \cdot 3(0.5)^{\star \star \star}$ & $2.3(0.5)^{\star \star \star}$ & $2 \cdot 0(0 \cdot 4)^{\star \star \star}$ \\
\hline & 9 & $4 \cdot 1(1 \cdot 5)$ & $2 \cdot 8(1 \cdot 3)^{\star}$ & $2 \cdot 6(1 \cdot 2)^{\star}$ & $2 \cdot 4(1 \cdot 3)^{\star}$ \\
\hline
\end{tabular}

means of simple or multiple regression procedures. A P value of $<0.05$ was considered significant.

\section{Results}

The haemodynamic data are presented in table 1. There was a significant difference in baseline pulmonary capillary wedge pressure between the groups $(P=0 \cdot 04)$. No other significant differences in the pretreatment haemodynamic variables were observed between the groups. Compared with placebo the decrease in pulmonary capillary wedge pressure expressed as relative change during the study was significant in the groups receiving $2.5 \mathrm{mg}(P=0.037)$ and $5 \mathrm{mg}(P=0.025)$ of ramipril. The mean arterial pressure decreased significantly with $5 \mathrm{mg}$ of ramipril compared with placebo $(P=0.002)$, whereas the relative decrease in systemic vascular resistance reached borderline significance in the groups receiving $2.5 \mathrm{mg}(P=0.047)$ and $5 \mathrm{mg}(P=0.052)$ of ramipril. The other haemodynamic responses did not differ between the groups. The plasma concentrations of atrial natriuretic peptide, arginine vasopressin, and ramiprilat and the plasma activities of angiotensin converting enzyme and renin are presented in table 2 . The only variable differing between the four groups at baseline was angiotensin converting enzyme activity $(P=0.001)$. There was no significant difference between the groups in atrial natriuretic peptide response during the study period. A significant decrease in the plasma concentration of arginine vasopressin with time was observed in all groups.

Figure 1 shows the relative changes in pulmonary capillary wedge pressure and atrial natriuretic peptide in the four groups.

\section{RELATIONS BETWEEN HAEMODYNAMIC DATA} AND ATRIAL NATRIURETIC PEPTIDE CONCENTRATION.

The relations at baseline between atrial natriuretic peptide concentration and pulmonary capillary wedge pressure, right atrial mean pressure, mean atrial pressure, heart rate, and cardiac index were tested by a stepwise multiple regression analysis. Pulmonary capillary wedge pressure and an inverse correlation with cardiac index were found to be significant and independent predictors $(P<0.001)$ of atrial natriuretic peptide concentration at baseline, the stronger relation being with pulmonary capillary wedge pressure $(r=0.78)$ (fig 2).

In the groups receiving $2.5 \mathrm{mg}$ and $5 \mathrm{mg}$ of ramipril, a significant decrease in pulmonary capillary wedge pressure compared with the baseline value was maintained 24 hours after the administration of the drug. No concomitant significant change in atrial natriuretic peptide concentration between baseline and 24 hours was observed in any of the groups. The fluctuations in right atrial mean pressure and cardiac index were similar in all groups.

The ratios of atrial natriuretic peptide concentration to pulmonary capillary wedge 
Baseline to $3 \mathrm{~h}$
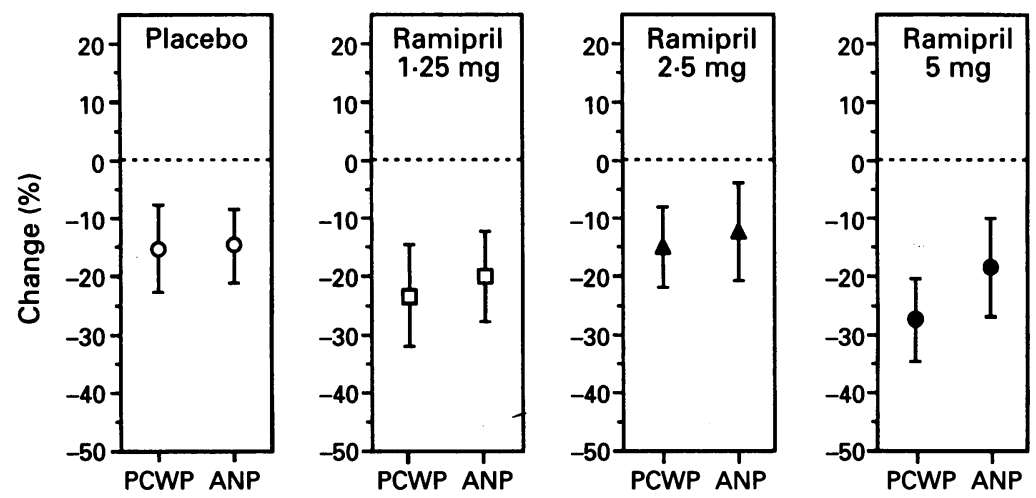

Baseline to $24 \mathrm{~h}$
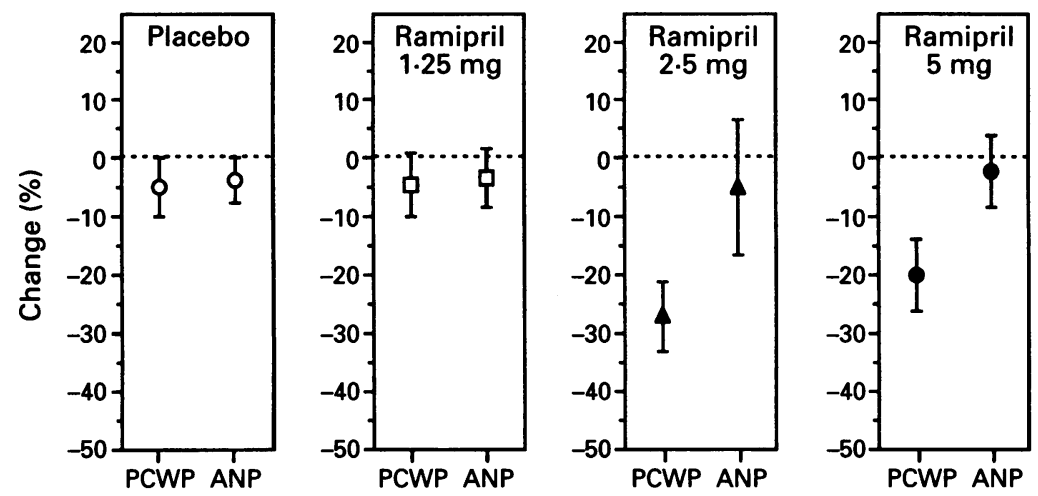

Figure 1 Percentage changes in atrial natriuretic peptide concentration (ANP) and pulmonary capillary wedge pressure (PCWP) from baseline to 3 hours and from baseline to 24 hours in the different groups.

Table 3 Ratios of plasma concentrations of atrial natriuretic peptide to pulmonary capillary wedge pressure

\begin{tabular}{llllll}
\hline $\begin{array}{l}\text { Ramipril } \\
(\mathrm{mg})\end{array}$ & Baseline & $3 h$ & $6 h$ & $24 h$ & $\begin{array}{l}\text { Change between } \\
\text { baseline and 24h (\%) }\end{array}$ \\
\hline 0 & $4 \cdot 2(2 \cdot 1)$ & $4 \cdot 2(2 \cdot 1)$ & $4 \cdot 4(1 \cdot 19)$ & $4 \cdot 4(2 \cdot 2)$ & $5(33)$ \\
$1 \cdot 25$ & $3 \cdot 7(2 \cdot 0)$ & $4 \cdot 0(2 \cdot 3)$ & $3 \cdot 7(2 \cdot 2)$ & $3 \cdot 8(2 \cdot 1)$ & $5(16)$ \\
$2 \cdot 5$ & $3.9(1 \cdot 9)$ & $4 \cdot 1(2 \cdot 2)$ & $4 \cdot 7(2 \cdot 1)$ & $4 \cdot 9(2 \cdot 7)^{\star}$ & $31(39)$ \\
5 & $3 \cdot 3(0 \cdot 9)$ & $3 \cdot 8(1 \cdot 5)$ & $3.9(1 \cdot 7)$ & $4 \cdot 1(1 \cdot 2)^{\star}$ & $27(28)$ \\
\hline$\star P=0.03$ & & & & &
\end{tabular}

$\star P=0.03$.

Figure 2 Relation between pulmonary capillary wedge pressure and atrial natriuretic peptide concentration at peptide concentration
baseline in the groups which subsequently received placebo or the three doses of ramipril pressure were therefore calculated to create a simple measure to compensate for the influence of pulmonary capillary wedge pressure on the plasma concentration of atrial natriuretic peptide. This ratio was not significantly altered in the group receiving placebo or in that receiving $1.25 \mathrm{mg}$ of ramipril. In contrast, the ratio increased significantly between base-

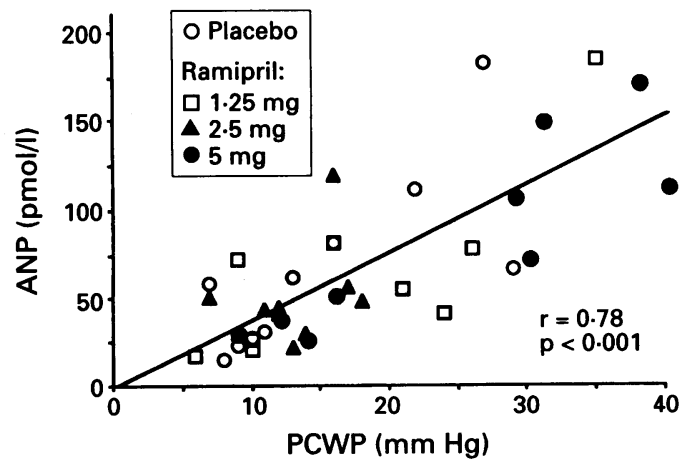

line and 24 hours in the groups that were given $2.5 \mathrm{mg}$ and $5 \mathrm{mg}$ of ramipril (both $P$ values $=0.03)($ table 3$)$.

The change in the ratio of atrial natriuretic peptide concentration to pulmonary capillary wedge pressure from baseline to 24 hours was not related to the baseline pulmonary capillary wedge pressure (simple regression). A multiple regression analysis was performed to test for possible influence of the previously tested haemodynamic parameters on this ratio. There were no significant interactions between the ratio and these parameters, apart from pulmonary capillary wedge pressure and atrial natriuretic peptide concentration, as was to be expected. The calculated change in the ratio of atrial natriuretic peptide concentration to pulmonary capillary wedge pressure was not influenced by any of the above differences but was exclusively dependent on the change in atrial natriuretic peptide concentration and change in pulmonary capillary wedge pressure.

In the placebo group there was a significant relation between change in pulmonary capillary wedge pressure and plasma concentration of atrial natriuretic peptide at 3,6 , and 24 hours ( $r$ values $0.77,0.70$, and 0.78 and $P$ values $0.01,0.03$, and 0.008 , respectively). The treatment group receiving $1.25 \mathrm{mg}$ of ramipril had a similar relation between change in these variables at 6 and 24 hours $(r>0.70$ and $P<$ 0.03 ), but not at 3 hours. There were no significant relations between change in pulmonary capillary wedge pressure and change in plasma concentration of atrial natriuretic peptide in the groups receiving the two higher doses of ramipril.

\section{RAMIPRILAT AND ARGININE VASOPRESSIN} CONCENTRATIONS, ENZYME ACTIVITIES, AND HAEMODYNAMIC DATA

Table 4 shows the relations between plasma concentrations of ramiprilat and haemodynamic alterations. No significant correlations with right atrial mean pressure, cardiac index, or plasma renin activity were found.

The change in pulmonary capillary wedge pressure was also proportional to the degree of angiotensin converting enzyme inhibition ( $r$ values $0.43-0.48 ; P$ values $0.01-0.03$ )

The degree of inhibition of angiotensin converting enzyme was proportional to the ramiprilat concentration, with a $50 \%$ inhibition around $1 \mathrm{ng} / \mathrm{ml}$ and total inhibition around $7 \mathrm{ng} / \mathrm{ml}$. The inhibition was long standing, amounting to $87 \%, 24$ hours after intake of $5 \mathrm{mg}$ of ramipril.

Arginine vasopressin concentration showed no significant correlation with the haemodynamic variables, ramiprilat concentration, or enzyme activities.

RELATION BETWEEN ENZYME ACTIVITIES AND ARGININE VASOPRESSIN, RAMIPRILAT, AND ATRIAL NATRIURETIC PEPTIDE CONCENTRATIONS.

No significant correlations were found between plasma renin activity, angiotensin converting enzyme activity, arginine vaso- 
Table 4 Relation between plasma concentration of ramiprilat and change in haemodynamic variables

\begin{tabular}{llll}
\hline Change in variable & $3 h$ & $6 h$ & $24 h$ \\
\hline Pulmonary capillary wedge pressure $(\mathrm{mm} \mathrm{Hg})$ & $r=0.50, \mathrm{P}=0.008$ & $r=0.42, \mathrm{P}=0.03$ & $r=0.56, \mathrm{P}=0.003$ \\
Mean arterial pressure $(\mathrm{mm} \mathrm{Hg})$ & $r=0.73, \mathrm{P}<0.001$ & $r=0.37, \mathrm{P}=0.05$ & $r=0.43, \mathrm{P}=0.03$ \\
Systemic vascular resistance $\left(\right.$ dyn $\left.\cdot \mathrm{s} \cdot \mathrm{cm}^{-5}\right)$ & $r=0.44, \mathrm{P}=0.02$ & $\mathrm{NS}$ & $\mathrm{NS}$ \\
Heart rate (beats/min) & $r=0.39, \mathrm{P}=0.046$ & $\mathrm{NS}$ & $\mathrm{NS}$ \\
\hline
\end{tabular}

pressin concentration, ramiprilat concentration, and atrial natriuretic peptide concentration, or with changes in these parameters (multiple regression).

\section{Discussion}

Atrial natriuretic peptide may be an important modulator of the complex neuroendocrinological adaptations in heart failure. ${ }^{129}$ Endogenous atrial natriuretic peptide has a significant vasodilator role in heart failure in studies using antibodies against this peptide in rats with chronic congestive heart failure. ${ }^{30}$ Lee et al reported that an increase in the plasma concentrations of atrial natriuretic peptide had a protective effect on kidney function during experimental hypotension. ${ }^{31}$ Evidence of interactions between the reninangiotensin-aldosterone system and atrial natriuretic peptide have also been presented..$^{910}$ 3233

\section{INFLUENCE OF ANGIOTENSIN CONVERTING ENZYME INHIBITION ON PLASMA CONCENTRATION OF ATRIAL NATRIURETIC PEPTIDE}

Richards et al found no change in the concentration of endogenous plasma atrial natriuretic peptide after a two hour combined infusion of captopril and low dose atrial natriuretic peptide. ${ }^{19}$ Their report was based on data collected when the effect of the atrial natriuretic peptide infusion had disappeared but the angiotensin converting enzyme inhibition was still present. Wilkins et al found a dose dependent rise in plasma concentrations of atrial natriuretic peptide after 48 hours of captopril treatment, ${ }^{17}$ whereas Mann et al noted a clear fall in subjects with sodium depletion who were given enalapril for four days. ${ }^{18}$ These findings may indicate that changes in plasma concentrations of atrial natriuretic peptide are not specifically related to angiotensin converting enzyme inhibition. In addition, the importance of the duration of the inhibition of angiotensin converting enzyme on the effects on the plasma concentration of atrial natriuretic peptide is not yet clear. Since concomitant changes in central (atrial) pressure were not assessed in the studies cited, the proposed resetting of the release mechanisms of atrial natriuretic peptide is still conceivable, and if present, may have influenced the results of previous studies. ${ }^{20}$

In our study haemodynamic variables and vasoactive hormones were examined in a group of patients with uniform disease during the first 24 hours of different degrees of angiotensin converting enzyme inhibition. Pulmonary capillary wedge pressure, the main predictor of plasma concentrations of atrial natriuretic peptide in our study, was significantly reduced when compared with the placebo group during the first 24 hours in the groups that were given $2.5 \mathrm{mg}$ and $5 \mathrm{mg}$ of oral ramipril. In contrast, the change in plasma concentration of atrial natriuretic peptide did not differ significantly between the groups. The plasma concentration of atrial natriuretic peptide was, however, lowest at three hours after baseline in all groups, with a tendency to return towards baseline values at 24 hours. This increase between three and 24 hours may be explained by a proportional increase in pulmonary capillary wedge pressure in the placebo group and the group given $1.25 \mathrm{mg}$ ramipril. Further support for this view is provided by the significant relation between change in pulmonary capillary wedge pressure and change in plasma concentrations of atrial natriuretic peptide in these groups. In the patients who received $2.5 \mathrm{mg}$ and $5 \mathrm{mg}$ ramipril the persistence of a significant reduction of this pressure at 24 hours makes another explanation necessary. In these patients the relation between change in pulmonary capillary wedge pressure and change in peptide concentration was lost. One possibility is that this observation reflects a fairly slow adaptive mechanism, in contrast to the rapid responsiveness to haemodynamic interventions previously reported. ${ }^{7}$ Alternatively, the cause may be a direct effect of the metabolite itself or alterations in the reninangiotensin-aldosterone system caused by changes in the angiotensin converting enzyme activity. These putative explanations were further analysed in a model adding a measure designed to compensate for the relation between atrial natriuretic peptide and pulmonary capillary wedge pressure.

RESETTING OF THE RELATION BETWEEN ATRIAL NATRIURETIC PEPTIDE CONCENTRATION AND PULMONARY CAPILLARY WEDGE PRESSURE

The possibility of resetting the relation between atrial pressure and atrial natriuretic peptide concentration during 24 hours of high degree inhibition of angiotensin converting enzyme is of special interest in the light of the strong correlation between atrial pressures and plasma concentrations of atrial natriuretic peptide reported from most studies. ${ }^{8}$ The ratio of atrial natriuretic peptide concentration to pulmonary capillary wedge pressure was therefore calculated to obtain a simple measure to allow comparisons over time, corrected for the change in pulmonary capillary wedge pressure. The reason for the observed resetting of the plasma atrial natriuretic 
peptide concentration to a higher level with a given pulmonary capillary wedge pressure in the groups of patients that received $2.5 \mathrm{mg}$ and $5 \mathrm{mg}$ of ramipril is not clear and somewhat surprising in the light of the proposed direct stimulating effect of angiotensin II infusions on atrial natriuretic peptide release in experimental animals. ${ }^{16}$ The increase in this ratio could not be explained by an increase in right atrial mean pressure, since this variable was reduced in all groups at 24 hours. Three other explanations may apply:

- Possible resetting of a stretch receptor in the atria caused by angiotensin converting enzyme inhibitory effects on the renin of angiotensin system or by effects of the metabolite. ${ }^{20}$

- An altered balance between arginine vasopressin and atrial natriuretic peptide concentration, favouring a comparatively higher plasma concentration of the latter peptide. ${ }^{34}$

- Fluid retention, increased plasma sodium concentrations, and altered regional blood flow such that blood and plasma are diverted from sites of atrial natriuretic peptide clearance, with effects including decreased renal clearance of this peptide.

Our observations, however, do not provide support for any of these hypotheses. Furthermore, the absence of significant relations between the other measured vasoactive hormones and plasma concentrations of atrial natriuretic peptide indicate that direct hormonal interactions are less important determinants of the in vivo plasma concentrations of atrial natriuretic peptide than pulmonary capillary wedge pressure in patients with congestive heart failure.

In a study in patients with dilated cardiomyopathy and mild heart failure Volpe et al showed that one week of treatment with an angiotensin converting enzyme inhibitor restored the cardiac and hormonal responses to volume overload..$^{35}$ Acute treatment with glyceryl trinitrate showed favourable effects on the haemodynamic adaptation to volume loading similar to those of angiotensin converting enzyme inhibition, but it did not restore the response of atrial natriuretic peptide to volume expansion. Two interpretations of these findings were suggested: either angiotensin converting enzyme inhibition has a direct effect in itself, or the restoration of atrial natriuretic peptide release related to the cardiac unloading produced by vasodilator treatment needs a more prolonged adaptation period than the two hours for which the infusion of glyceryl trinitrate was maintained. These results are compatible with our findings of an altered ratio of atrial natriuretic peptide concentration to pulmonary capillary wedge pressure ratio after 24 hours but not after three hours of high degree angiotensin converting enzyme inhibition. A similar shift in the relation between atrial natriuretic peptide concentration and atrial pressure was not found during a 24 hour infusion of glyceryl trinitrate in a catheterisation study in which both atrial pressures and plasma concentra- tions of atrial natriuretic peptide were measured..$^{36}$ In this last study, however, there was a gradual return towards baseline values as tolerance to glyceryl trinitrate developed.

Considerable variation in vasoactive hormone concentrations between people is a well recognised phenomenon. ${ }^{2}$ We found pronounced interindividual variations in the plasma concentration of atrial natriuretic peptide with similar pulmonary capillary wedge pressures, whereas the intraindividual variations were limited, especially between baseline and 24 hours despite significant haemodynamic changes. The pronounced interindividual variations with similar pulmonary capillary wedge pressures indicates that the individual plasma concentration of atrial natriuretic peptide is determined by multiple interactive factors, which may differ considerably between patients.

Rapid and graded changes in atrial natriuretic peptide concentration have been reported to occur during interventions that rapidly alter atrial pressures. ${ }^{7}$ We observed, however, a gradual increase in the calculated ratio of atrial natriuretic peptide concentration to pulmonary capillary wedge pressure in the groups receiving $2.5 \mathrm{mg}$ and $5 \mathrm{mg}$ of ramipril. This observation seems to be due to a gradual return towards the individual baseline plasma concentration in spite of a sustained and significant reduction in pulmonary capillary wedge pressure at 24 hours. This phenomenon may reflect rather slowly acting adaptive mechanisms favouring conservation of the individual plasma concentration of atrial natriuretic peptide.

\section{LIMITATIONS OF THE STUDY}

When atrial pressures depend on plasma concentrations of a vasoactive hormone, as they do on atrial natriuretic peptide, and where the study group is not large, significant interactions between atrial natriuretic peptide and the test drug, or involved hormones, might escape detection. The compensatory mechanisms during heart failure are complex, and other vasoactive hormones that were not measured in this study might have had an impact on our results. Although repeated measures of neurohormonal factors would add important information, the amount of blood sampling in this study was restricted to $200 \mathrm{ml}$ to avoid a systematic flaw due to decreased blood volume. Haemodynamic alterations are well recognised during catheterisation studies, and a vasodilative effect of eating on haemodynamics have also been described. ${ }^{37}$ In our study the patients ate one hour before the observations obtained at three and 24 hours. Measurements on these occasions therefore probably include effects of both eating and treatment. The significant fluctuations of hormones and haemodynamics in the placebo group highlights the necessity to include a placebo control in studies on the effects of vasodilatory drugs. Even so, the influences of the experimental procedure itself and of eating, in addition to the effects of the angiotensin converting enzyme inhibitor, may 
have reduced the possibilities of detecting direct effects of the angiotensin converting enzyme inhibition in our study.

\section{CONCLUSION}

In conclusion, whatever the exact mechanism of the relatively higher plasma concentration of atrial natriuretic peptide with a given pulmonary capillary wedge pressure after 24 hours, such an alteration of the relation between atrial natriuretic peptide and central haemodynamics may contribute to the beneficial effects of treatment with an angiotensin converting enzyme inhibitor in patients with congestive heart failure due to ischaemic heart disease.

This study was supported by grants from the Swedish Society of Physicians, the Swedish Heart and Lung Foundation, the Swedish Medical Research Council (7464), and Svenska Hoechst AB.

1 Anand IS, Ferrari R, Kalra GS, Wahi PL Poole-Wilson PA, Harris PC. Studies of body water and sodium, renal function, hemodynamic indexes, and plasma hormones in untreated congestive cardiac failure. Circulation 1989;80:299-305.

2 Francis GS, Goldsmith SR, Levine TB, Olivari MT, Cohn $\mathrm{NN}$. The neurohumoral axis in congestive heart failure Ann Intern Med 1984;101:370-7.

3 Nicholls MG, Fitzpatrick MA, Grozier IG. Converting enzyme inhibitors in heart failure. Eur Heart $\mathscr{f}$ 1989;9(suppl H):77-83.

4 Bolli P, Müller FB, Linder L, et al. The vasodilator potency of atrial natriuretic peptide in man. Circulation potency of atrial

5 deBold AJ, Borenstein HB, Veress AT, Sonnenberg H. A rapid and potent natriuretic response to intravenous injection of atrial

6 Wharton J, Anderson RH, Springall D, et al. Localisation of atrial natriuretic peptide immunoreactivity in the ventricular myocardium and conduction system of the human fetal and adult heart. Br Heart $\mathcal{f} 1988 ; 60: 267-74$

7 Waldman HM, Palacios IF, Block PC, et al. Responsiveness of plasma atrial natriuretic factor to short-term changes in left atrial haemodynamics after percutaneous balloon mitral valvuloplasty. $尹 A C C$ 1988;12:649-55.

8 Mancini GBJ, McGillem MJ, Bates ER, Weder AB, DeBoe SF, Grekin RJ. Hormonal response to cardiac tamponade: inhibition of release despite

9 Anderson JV, Struther AD, Payne NN, Slater JDH, Bloom $\mathrm{SR}$. Atrial natriuretic peptide inhibits the aldosterone response to angiotensin II in man. Clin Sci 1986;70:507-12.

10 McMurray J, Struthers AD. Atrial natriuretic factor inhibits isoproterenol- and furosemide-stimulated renin release in humans. Hypertension 1989;13:9-14.

11 Lee RW, Gay RG, Goldman S. Atrial natriuretic peptide reverses angiotensin-induced venoconstriction in dogs. Am $₹$ Physiol 1989;257:H1062-7.

12 Manning PT, Schwartz D, Katsube NC, Holmberg SW, Needleman P. Vasopressin-stimulated release of atriopeptin: endocrine antagonists in fluid homeostasis. opeptin: endocrine antagc $1985 ; 229: 395-7$.

13 Uehlinger ED, Weidman P, Gnaedinger MP, Shaw S, Lang RE. Depressor effects and release of atrial natriuretic peptide during norepinephrine or angiotensin II infusion in man. $\mathcal{F}$ Endocrinol Metab 1986;63:669-74.

14 Stasch J-P, Hirth-Dietrich C, Kazda S, Neuser D Endothelin stimulates release of atrial natriuretic peptides in vitro and in vivo. Life Sci 1989;45:869-75.

15 Dietz JR. The effect of angiotensin II on the secretion of atrial natriuretic factor (42678). Proc Soc Exp Biol Med 1988;187:366-9.
16 Volpe M, Pepino P, Lembo G, et al. Modulatory role of angiotensin-II in the secretion of atrial natriuretic factor in rabbits. Endocrinology 1991;128:2427-31.

17 Wilkins MR, Lewis HM, West MJ, Kendall MJ, Lote CJ Captopril reduces the renal response to intravenous trial natriuretic peptide in normotensives. f Hum Hypertens 1987;1:47-51.

18 Mann FE, Lang RE, Leidig M, Ritz E. Effect of angiotensin I converting enzyme inhibition on circulating atrial natriuretic peptide in humans. Klin Wochensch 1986;64(suppl VI):13-5.

19 Richards AM, Rao G, Espiner EA, Yandle T. Interaction of angiotensin converting enzyme inhibition and atrial natriuretic factor. Hypertension 1989;13:193-9.

20 Rouleau J-L, Bichet D, Kortas C. Atrial natriuretic peptide in congestive heart failure: postural changes and reset with chronic captopril therapy. Am Heart $f$ 1988;115:1060-7.

21 Tang J, Webber RJ, Chang D, Chang JK, Kiang J, Wei ET. Depressor and natriuretic activities of several atrial peptides. Regul Pept 1984;9:53-9.

22 Todd AP, Benfield P. Ramipril-a review of its pharmacological properties and therapeutic efficacy in cardiovascular disorders. Drugs 1990;39:110-35.

23 Berglund H, Boukter S, Theodorsson E, Vallin H, Edhag $O$. Raised plasma concentrations of atrial natriuretic peptide are independent of left atrial dimensions in patients with chronic atrial fibrillation. $\mathrm{Br}$ Heart $\mathcal{f}$ 1990;64:9-13.

24 Eckert HG, Münscher G, Oekonomopulos R, Strecker H, Urbach $H$, Wissmann $H$. A radioimmunoassay for the angiotensin converting enzyme inhibitor ramipril and its active metabolite. Arzneimittelforschung. 1985;35. active $1251-6$.

25 Metzger H, Maier R, Sitter C, Stern H-O. 2-[N-[(S)-1Ethoxycarbonyl-3-phenylpropyl]-L-alanyl]-(1S,3S,5S)-2azabicyclo[3.3.0] octane-3-carboxylic acid (Hoe 498)- a new and highly effective angiotensin I converting enzyme inhibitor. Arzneimittelforschung. 1984;34: 1402-6.

26 Malvano R, Zuchelli GC, Rosa U, Salvetti A. Measurement of plasma renin activity by angiotensin I radioimmunoassay. I. An assessment of some methodological aspects. Fournal of Nuclear Biology and Medicine 1972;16:24-31.

27 Edwards BS. Vasopressin. In: Gray CH, James VHT, eds. Hormones in blood. New York: Academic Press, 1979: Hormones

28 Theodorsson E. BASIC computer program to summarize data using nonparametric and parametric statistics including Anderson-Darling test for normality. Comput Methods Programs Biomed 1988;26:207-14.

29 Fyhrquist F, Tikkanen I. Atrial natriuretic peptide in congestive heart failure. Am $\mathcal{f}$ Cardiol 1988;62:20-4A

30 Drexler H, Hirth C, Stasch H, Neuser D, Just H. Vasodilatory action of endogenous atrial natriuretic factor in a rat model of chronic heart failure as determined by monoclonal ANF antibody. Circ Res 1990;66:1371-80.

31 Lee ME, Miller WL, Edwards BS, Burnett JC Jr. Role of endogenous atrial natriuretic factor in acute congestive heart failure. $¥$ Clin Invest $1989 ; 84: 1962-6$.

32 Gaillard CA, Koomans HA, Mees EJD. Enalapril attenuates natriuresis of atrial natriuretic factor in humans. ates natriuresis of atrial natrin
Hypertension 1988;11:160-5.

33 Salazar FJ, Granger JP, Fiksen-Olsen MJ, Bentley MD Romero JC. Possible modulatory role of angiotensin II on atrial peptide-induced natriuresis. Am f Physiol 1987, 253:F880-3.

34 Morris M, Cain M, Chalmers J. Complementary changes in plasma atrial natriuretic peptide and antidiuretic hormone concentrations in response to volume expansion and haemorrhage: studies in conscious normotensive and spontaneously hypertensive rats. Clin Exp Pharmacol Physiol 1987;14:283-9.

35 Volpe $M$, Tritto $C$, de Luca $N$, et al. Angiotensin convert ing enzyme inhibition restores cardiac and hormonal ing enzyme inhibition restores cardiac and hormonal responses to volume overload in patients with dilated cardiomyopathy

36 Lewis BS, Makhoul N, Dakak N, et al. Atrial natriuretic peptide in severe heart failure: response to controlled changes in atrial pressures during intravenous nitroglycerin therapy. Am Heart $\mathcal{F}$ 1992;124:1009-16.

37 Packer M, Medina N, Yushak M. Hemodynamic changes mimicking a vasodilator drug response in the absence of drug therapy after right heart catheterization in patients with chronic heart failure. Circulation 1985;71:761-6. 